\title{
Metabolic Adaptations Due to the Inclusion of Pasture in the Diet of Dairy Cows Fed Total Mixed Ration during Early Lactation
}

\section{Ana Laura Astessiano ${ }^{*}$, Ana Meikle², Pablo Chilibroste1, Diego Antonio Mattiauda1, M. Fajardo', Mariana Carriquiry ${ }^{1}$}

${ }^{1}$ Facultad de Agronomía, Universidad de la República, Montevideo, Uruguay

${ }^{2}$ Facultad de Veterinaria, Universidad de la República, Montevideo, Uruguay

Email: ^lauaste@gmail.com

How to cite this paper: Astessiano, A.L., Meikle, A., Chilibroste, P., Mattiauda, D.A., Fajardo, M. and Carriquiry, M. (2017) Metabolic Adaptations Due to the Inclusion of Pasture in the Diet of Dairy Cows Fed Total Mixed Ration during Early Lactation. Open Journal of Animal Sciences, 7, 127-140. https://doi.org/10.4236/ojas.2017.72011

Received: December 25, 2016

Accepted: April 16, 2017

Published: April 19, 2017

Copyright $\odot 2017$ by authors and Scientific Research Publishing Inc. This work is licensed under the Creative Commons Attribution International License (CC BY 4.0).

http://creativecommons.org/licenses/by/4.0/

(c) (i) Open Access

\begin{abstract}
The aim of this study was to evaluate the metabolic adaptations due to the inclusion of pasture in the diet of dairy cows fed on a total mixed ration (TMR) ad libitum during early lactation. Multiparous cows $(\mathrm{n}=18)$ were used in a randomized complete block design and were randomly assigned according to parity, BW and BCS to one of two feeding strategies from calving to 60 DIM: 1) cows fed TMR ad libitum (without access to pasture; 100\% TMR) and 2) cows fed on a mixed system with pasture grazing ( $6 \mathrm{~h}$ of access to paddock in one grazing session, 8:00 to 14:00 h) and supplemented with 50\% of ad libitum TMR (Pasture Group, PG). At 61DIM, TMR fed cows were assigned without an adjustment period to a similar feeding and management routine than PG group (Post-TMR), while PG cows remained in their original routine throughout the experiment. Thus, at 61DIM and thereafter, both, PG and Post-TMR cows grazed a second-year pasture and were supplemented with 50\% TMR (DM basis). Milk production was determined daily until 80 DIM, and cow BCS and BW were registered and blood samples and liver biopsies were obtained one week before and one week after dietary change $(-1$ to +1 wk; +55 and +69 DIM). Milk yield, BW and BCS did not differ between treatments but decreased or tended to decreased from -1 to +1 wk only in Post-TMR cows. Serum IGF-1 tended to increase in Post-TMR cows. Hepatic expression of $I G F B P 5$ and IGFBP6 mRNA, were greater while $I G F 1$ and $I G F B P 3$ mRNA tended to be greater for Post-TMR than PG cows. Hepatic expression of $I G F 1, I G F B P 5$ and IGFBP6 mRNA increased from -1 to $+1 \mathrm{wk}$ only in Post-TMR cows. Expression of $A C A D V L$ and $P D H 1 A$ mRNA had a 2 -fold increase in both groups from wks -1 to +1 . The results confirm that changes in feeding strategy without an adaptation period modified animal metabolism. The inclusion of grazing to cows that were fed TMR during early
\end{abstract}


lactation, increased IGF-1 concentrations and modified hepatic expression of genes related with IGF system and fatty acid metabolism indicating redistribution of nutrients and energy towards maintenance requirements (increased due to walking and grazing activity) in detriment of milk production.

\section{Keywords}

Turnout to Pasture, Hepatic Expression, Dairy Cattle

\section{Introduction}

Pasture-based systems allow low-cost and high-nutritional value feeding in dairy cows, and offer benefits for animal welfare and environmental care [1]. However, the quantity and quality of the pasture offered is variable throughout the year, determining an imbalance between nutrient supply and demand at various stages of the production cycle of the modern dairy cow [2]. Thus, the inclusion of concentrates and silages in the dairy cow diet has increased to meet the requirement of the milking herd [3] [4]. In this regard, the use of a total mixed ration (TMR) in early lactation allows dairy cows achieve maximum performance in times of reduced pasture dry matter (DM) production, determining an increase in milk yield, cow body condition score (BCS), metabolic status and reproductive performance [5] [6] [7].

The transition from a TMR to a pasture based systems involved significant changes in feed intake [8], cow behavior and activity [3], and rumen microbiota [9] causing changes in milk production and composition [10] [11]. However, litthe is known about dairy cow metabolic adaptations to changes in feeding regimes, from a TMR diet in early lactation (0 - 60 days in milk; DIM) to a pasture-based diet in a later stage of lactation. Metabolic adaptations during the transition from a TMR to a pasture-based diet (+1.75 or $3.6 \mathrm{~kg}$ DM of concentrate) in mid-lactation cows (160 to 200 DIM) included decreased insulin and increased non-esterified fatty acids (NEFA) and beta-hydroxybutyrate (BHB), indicating an increased lipomobilization during the first days or weeks on pasture, associated to decreased dry matter intake (DMI), milk yield and BCS [11] [8]. Nevertheless, liver changes on the somatotrophic axis and energy - glucose and fatty acid - metabolism in response to this dietary change has been scarcely reported and understood. Better understanding of the effects of different feeding strategies on animal metabolism and performance will promote improvements in actual feeding practices. To our knowledge, there are no studies that evaluated energy metabolism when TMR-fed dairy cows are changed to a feeding regime that included pasture grazing and an appropriate supplementation.

We hypothesized that when cows in early lactation change from a 100\% TMR to a pasture $+50 \%$ TMR feeding regime, metabolism would rapidly adapt in order to cope with changes in amount and type of nutrients absorbed as well as in energy balance. Therefore, the aim of this study was to examine alterations in 
metabolic and endocrine profiles as well as hepatic expression of genes related with nutrient partitioning and energy metabolism when dairy cows fed TMR ad libitum during the first 60 DIM (100\% TMR) changed to a feeding regime that included pasture grazing $(6 \mathrm{~h} / \mathrm{d})$ and supplementation with a reduced allowance of TMR (50\%) without an adaptation period.

\section{Materials and Methods}

The experiment was performed according to the protocol approved by the Animal Experimentation Committee (CHEA) of the Universidad de la República (UdelaR, Uruguay). It was carried out the Experimental Station "Dr. Mario A. Cassinoni” of the School of Agronomy (Paysandú, Uruguay).

\subsection{Animals and Experimental Design}

Eighteen multiparous Holstein cows (fall calving; body weight $(\mathrm{BW})=709 \pm$ $52.5 \mathrm{~kg}$ and $\mathrm{BCS}=3.25 \pm 0.25$ units and parity $=4.5 \pm 1.7$ ) were used in a randomized block design with two replications (groups). Cows were grouped according to their due calving date (beginning and end of fall) and were randomly assigned within group according to their parity, BW and BCS to one of two feeding strategies from calving (day 0) to 60 DIM: 1) cows fed a TMR ad libitum (without access to pasture) and 2) cows fed on a mixed system with grazing (6 h of access to paddock in one grazing session, 8:00 to 14:00 h) and supplemented with $50 \%$ of ad libitum TMR (PG). At61 \pm 2 DIM, TMR fed cows were assigned without an adjustment period to a similar feeding and management routine than PG group (Post-TMR), while PG cows remained in their original routine throughout the experiment. Therefore, in the present study we evaluated two treatments: Post-TMR (0 to 60 DIM fed TMR and 61 to 80 DIM fed pasture grazing $+50 \%$ TMR) and PG as a control group (0 to 80 DIM pasture grazing + $50 \%$ TMR). Details on cow feeding and management during the prepartum and early postpartum as well as productive, metabolic, endocrine and reproductive responses during the first 60 DIM have been previously reported [6] [7].

At 61 DIM, all cows (PG and Post-TMR) grazed a second-year pasture of Festuca arundinacea, Trifoliumrepens and Lotus corniculatus (located $1.7 \mathrm{~km}$ from the milking parlour) in a 7-d rotation system with a mean herbage allowance at $4 \mathrm{~cm}$ above the ground level of $15 \mathrm{~kg} \mathrm{DM} / \mathrm{cow} / \mathrm{d}(279 \pm 14 \mathrm{DM} \mathrm{g} / \mathrm{kg}$, and $184 \pm 14 \mathrm{~g} / \mathrm{kg}$ DM of crude protein (CP), and $201 \pm 2.5 \mathrm{~g} / \mathrm{kg} \mathrm{DM}$ acid detergent fiber (FDA)). The TMR was offered once a day in the afternoon (after pm milking), had a forage/concentrate ratio of 45/55 (dry basis) and was composed of sorghum silage (0.45) and a concentrate that included ground corn (0.19), wheat (0.12), soybean expeller (0.09), sunflower expeller (0.11), urea (0.003) and minerals and vitamins (0.009) $(597 \pm 43 \mathrm{DM} \mathrm{g} / \mathrm{kg}, 167 \pm 18 \mathrm{~g} / \mathrm{kg} \mathrm{DM}$ PC, and $141 \pm$ $16.0 \mathrm{~g} / \mathrm{kg}$ DM FDA).

Cows were milked twice a day (5:00 and 15:00 h) and milk production was determined daily from 61 until 80 DIM of lactation. Milk samples to determine fat, protein and lactose composition and BCS (score 1 a 5) [12], BW, blood sam- 
ples and liver biopsies were obtained one week before and one week after dietary change ( -1 and 1 wk relative to dietary change or +55 and +69 DIM). Blood samples were obtained in heparinized tubes by venipuncture of the coccygeal vein and were centrifuged $\left(2000 \mathrm{xg}\right.$ for $15 \mathrm{~min}$ at $\left.4^{\circ} \mathrm{C}\right)$ within $2 \mathrm{~h}$ after collection and serum was stored at $-20^{\circ} \mathrm{C}$ until assayed. After blood collection, liver biopsies $\left(500 \mathrm{mg}\right.$ ) were obtained using a 14-gauge biopsy needle (Tru-Core ${ }^{\oplus}$-II Automatic Biopsy Instrument; Angiotech, Lausanne, Suitzerland) as described by Carriquiry et al. [13]. Liver samples were immediately frozen in liquid nitrogen and stored at $-80^{\circ} \mathrm{C}$ until total RNA was isolated.

\subsection{Metabolite and Hormone Analyses}

Concentrations of serum NEFA, BHB, glucose and urea were determined by colorimetric assays using commercial kits according to [7]. Concentrations of insulin, IGF-1 and leptin were measured using commercial kits by immunoradiometric assays (IRMA, for insulin and IGF-1) or by a liquid-phase radioimmunoassay (RIA, for leptin). Assay details and detection limits as well as intra-assay $\mathrm{CV}$ were described in Astessiano et al. [7].

\subsection{Isolation and Purification of RNA}

Isolation of total RNA from hepatic tissue and synthesis of cDNA by reverse transcription was performed according with Astessiano et al. [7]. Primers (Supplementary Table $\mathrm{S} 1$ ) to specifically amplify cDNA of target genes: $I G F 1, I G F 2$, IGF binding proteins-1 to 6 (IGFBP 1, IGFBP2, IGFBP3, IGFBP4, IGFBP5, $I G F B P 6)$, insulin receptor (INSR), and long isoform of leptin receptor (LEPRB), glucose 6-phosphatase ( $G 6 P C$ ), pyruvate carboxylase $(P C)$, pyruvate dehydrogenase $(P D H 1 A)$, acyl-CoA oxidase $(A C O X)$, carnitine palmitoyltransferase $(C P T 1 A)$, acyl-CoA dehydrogenase very long chain $(A C A D V L)$, hydroxymethylglutaryl-CoA synthase (HMGCoA), citrate cintase (CS), and from endogenous controls: $\beta$-actin (ACTB), hypoxanthine phosphoribosyl transferase (HPRT), and ribosomal protein $S 9$ (RPS9) were used [7].

Real time PCR reactions were performed in a total volume of $15 \mu \mathrm{L}$ using KAPA SYBR ${ }^{\circledast}$ FAST Universal 2X qPCR Master Mix (KapaBiosystems, inc. Woburn, MA, USA) according with [14]. Gene expression one week after dietary change ( $+1 \mathrm{wk})$ was measured by relative quantification [15] to the expression of one week before dietary change ( $-1 \mathrm{wk})$ and normalized to the geometric mean expression of the endogenous control genes (HPRT, ACTB and RPS9). Expression stability of 3 selected housekeeping genes was evaluated using MS-Excel add-in Normfinder (MDL, Aarhus, Denmark). The stability values obtained with Normfinder they were $0.144,0.121$, and 0.178 for HPRT, ACTB, and RPS9, respectively. Amplification efficiencies or target and endogenous control genes were estimated by linear regression of a dilution cDNA curve ( $\mathrm{n}=5$ dilutions, from 100 to $6.25 \mathrm{ng} /$ tube). Intra and inter-assay CV values were $1.9 \%$ and $4.2 \%$, respectively. 


\subsection{Calculation and Statistical Analyses}

Net energy (NE) calculations was based on [16]. Maintenance NE requirements were calculated as NEM $=0.08 \times \mathrm{BW}^{\wedge} 0.75+$ NEmact, where NEmact $=((($ Distance $/ 1000) \times$ Trips $) \times(0.00045 \times \mathrm{BW}))+(0.0012 \times(\mathrm{BW}))$. Lactation NE requirements were calculated as NEL $=$ milk yield $\times[(0.0929 \times$ fat $\%)+(0.0563 \times$ true protein $\%)+(0.0395 \times$ lactose $\%)]$, using composition data derived from analysis of samples collected weekly.

Data were analyzed in a randomized block design using the SAS System program (SAS Institute Inc., Cary, NC, USA). Univariate analyses were performed on all variables to identify outliers and inconsistencies and to verify normality of residuals. Data of milk production, BW, BCS, and serum metabolite and hormone concentrations were analyzed by repeated measures using the MIXED procedure with DIM as the repeated effect, and the unrestricted (UN) covariance structure. The model included the treatment (PG vs. Post-TMR), week (before and after dietary change), and the interaction between treatment and week as fixed effects, replication as a random effect and calving date as a covariate. The Kenward-Rogers procedure was used to adjust the denominator degree of freedom. Tukey-Kramer tests were conducted to analyze differences between treatments and weeks $(\alpha=0.05)$. Data of hepatic gene expression were analyzed using the MIXED procedure with a model that included treatment as fixed effect, replication as a random effect and calving date as a covariate. One-way t-test were conducted to assess week effect within treatment. Correlation coefficients were estimated using the CORR procedure. Data are presented as least square means \pm pooled standard errors.

\section{Results}

Milk yield did not differ between treatments $(\mathrm{P}=0.16)$ but decreased $(\mathrm{P}<0.05)$ from -1 to +1 wk only in Post-TMR (Figure $1(\mathrm{~A})$ ) whereas milk NEL output and milk composition was not affected $(\mathrm{P}>0.10)$ by treatment or week. Cow BW and BCS tended to be affected by treatment and week $(\mathrm{P}=0.12)$ as they decreased $(\mathrm{P}=0.03)$ from -1 to +1 wk only in Post-TMR cows (Figure $1(\mathrm{~B})$ and Figure $1(\mathrm{C})$ ). Maintenance NEL requirement was affected by the interaction between treatment and week $(\mathrm{P}=0.01)$ as while it did not change from -1 to +1 wk in PG cows (12.81 to $12.66 \pm 0.3 \mathrm{Mcal} / \mathrm{d})$, an increase $(\mathrm{P}<0.05)$ was observed in Post-TMR cows (10.73 to $11.91 \pm 0.3 \mathrm{Mcal} / \mathrm{d}$ ).

Serum concentrations of NEFA, BHB, urea and glucose were not affected by treatment or week (Table 1). Serum IGF-1 concentrations were not affected by treatment or week but tended to be affected by the interaction between treatment and week $(P=0.06)$ as they tended to increase in Post-TMR cows with the change of diet ( 129.5 vs. $167.5 \pm 13.5 \mathrm{ng} / \mathrm{mL}$ from -1 to $+1 \mathrm{wk}$, respectively). Concentrations of insulin and leptin were not affected by treatment, week or their interaction (Table 1).

Hepatic expression of IGFBP5 and IGFBP6 mRNA ( $\mathrm{P}<0.05)$, were greater while IGF1 and IGFBP3 mRNA tended to be greater $(\mathrm{P}=0.14)$ for Post-TMR 

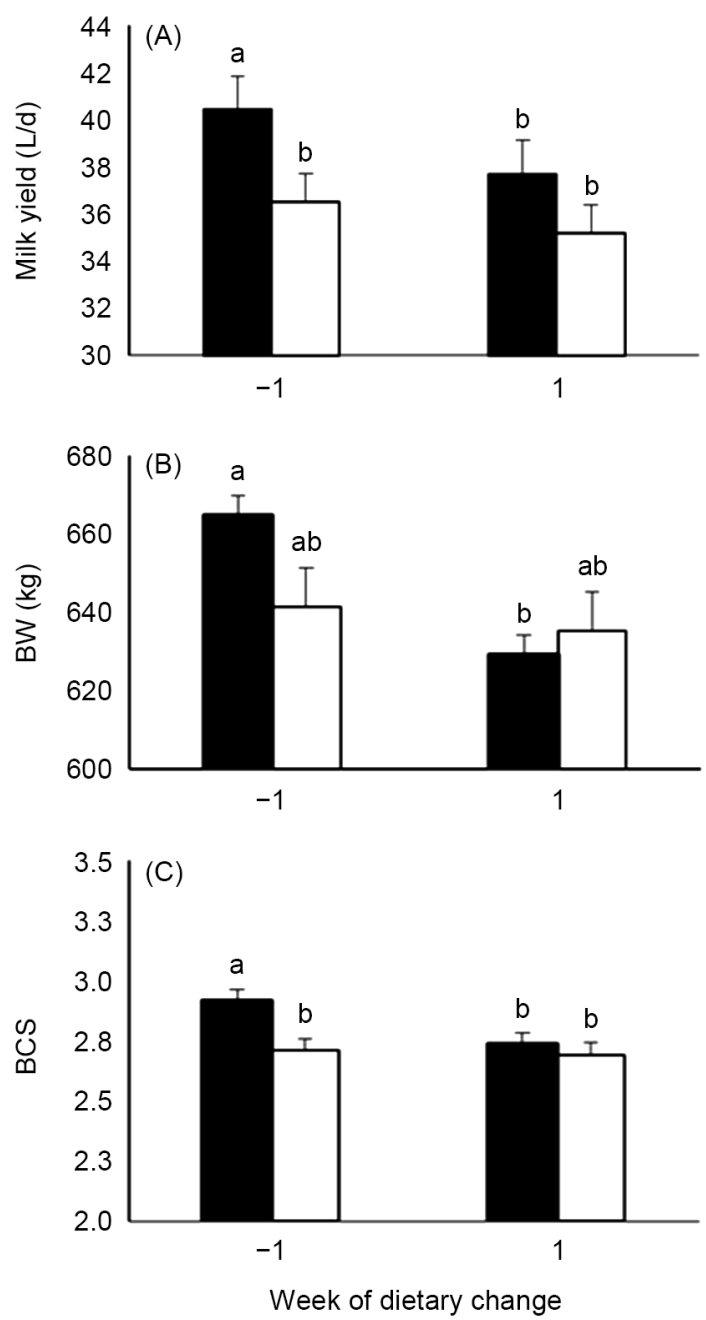

Figure 1. Changes in milk yield, BW and BCS one week before and one week after dietary change (+55 and +69 DIM, respectively) in multiparous dairy cows (Post-TMR; $\mathbf{\square}$ and PG; $\square)$. Within treatments: a vs b indicates significant differences $(\mathrm{p}<0.05)$.

Table 1. Effect of dietary change on serum metabolite and hormone concentrations in multiparous dairy cows.

\begin{tabular}{ccccccc}
\hline & \multicolumn{2}{c}{ Treatments $^{1}$} & & \multicolumn{3}{c}{ Pvalue } \\
\cline { 2 - 7 } & Post-TMR & PG & SE & T & WK & T x WK \\
\hline NEFA (mmol/L) & 0.6 & 0.5 & 0.06 & 0.66 & 0.56 & 0.20 \\
BHB $(\mathrm{mmol} / \mathrm{L})$ & 0.4 & 0.5 & 0.04 & 0.65 & 0.14 & 0.25 \\
Urea $(\mathrm{mmol} / \mathrm{L})$ & 5.3 & 5.3 & 0.50 & 0.96 & 0.88 & 0.56 \\
Glucosa $(\mathrm{mmol} / \mathrm{L})$ & 4.2 & 4.0 & 0.04 & 0.23 & 0.57 & 0.58 \\
IGF-I $(\mathrm{ng} / \mathrm{mL})$ & 148.5 & 143.5 & 13.40 & 0.83 & 0.91 & 0.06 \\
Insulina $(\mu \mathrm{IU} / \mathrm{mL})$ & 17.5 & 18.4 & 1.50 & 0.69 & 0.47 & 0.62 \\
Leptina $(\mathrm{ng} / \mathrm{mL})$ & 4.1 & 3.6 & 0.50 & 0.53 & 0.45 & 0.47 \\
\hline
\end{tabular}

${ }^{1}$ Post-TMR: Cows changed at 61 DIM to a mixed feeding regime that included pasture grazing (one am grazing session of $6 \mathrm{~h}$ ) $+50 \%$ TMR (DM basis) after being fed 100\% TMR (ad libitum) during the first 60 DIM. PG: control group, cows fed a mixed feeding regime of pasture grazing (one am grazing session of 6 h) $+50 \%$ TMR (DM basis) from calving. T: treatment; WK: week relative to dietary change. 
than PG cows (Table 2). In addition, expression of IGF1, IGFBP5 and IGFBP6 mRNA had a 2.3 to 3.4 -fold increase $(\mathrm{P}<0.025)$ from -1 to +1 wk only in PostTMR cows. Expression of IGF2, IGFBP1, IGFBP2, IGFBP4, INSR, and LEPRB mRNA were not affected by treatments $(\mathrm{P}>0.22$; Table 2$)$. Expression of the genes related to glucose and fatty acid metabolism in the liver did not differ $(\mathrm{P}>$ 0.50 ) between treatments (Table 2), but $A C A D V L$ and $P D H 1 A$ mRNA had a 2 -fold increase $(\mathrm{P}<0.01)$ in both groups from -1 to $+1 \mathrm{wk}$. In addition, the ratio $P D H 1 A$ to $P C$ mRNA tended $(\mathrm{P}=0.07)$ to have a 1.5 -fold increase from -1 to +1 wk only in Post-TMR cows. Independently of treatment, hepatic $A C A D V L$ mRNA was positively linearly correlated with serum NEFA concentrations $(\mathrm{r}=$ $0.71, \mathrm{P}=0.07)$.

Table 2. Effect of dietary change on relative hepatic mRNA expression of genes related to IGF system, glucose and fatty acid metabolismin multiparous dairy cows.

\begin{tabular}{|c|c|c|c|c|}
\hline & \multicolumn{3}{|c|}{ Treatments } & \multirow{2}{*}{ P value } \\
\hline & Post-TMR & PG & SE & \\
\hline$I G F 1$ & 2.41 & 1.00 & 0.25 & 0.14 \\
\hline$I G F 2$ & 1.00 & 0.97 & 0.20 & 0.96 \\
\hline$I G F B P 1$ & 0.60 & 1.22 & 0.13 & 0.22 \\
\hline$I G F B P 2$ & 0.95 & 1.00 & 0.12 & 0.93 \\
\hline$I G F B P 3$ & 1.33 & 0.76 & 0.20 & 0.14 \\
\hline IGFBP4 & 0.84 & 1.05 & 0.16 & 0.66 \\
\hline$I G F B P 5$ & 3.43 & 0.75 & 0.35 & 0.01 \\
\hline IGFBP6 & 2.32 & 0.66 & 0.12 & 0.04 \\
\hline$I N S R$ & 1.03 & 0.83 & 0.11 & 0.65 \\
\hline$L E P R B$ & 1.46 & 1.46 & 0.12 & 0.99 \\
\hline$A C A D V L$ & 2.01 & 1.85 & 0.23 & 0.80 \\
\hline$A C O X$ & 1.20 & 1.47 & 0.12 & 0.46 \\
\hline CS & 1.18 & 1.49 & 0.24 & 0.65 \\
\hline$P C$ & 1.32 & 1.47 & 0.24 & 0.80 \\
\hline$G 6 P C$ & 1.16 & 1.48 & 0.11 & 0.63 \\
\hline HMGCOAS & 1.92 & 1.56 & 0.12 & 0.79 \\
\hline$P D H 1 A$ & 2.09 & 1.78 & 0.14 & 0.62 \\
\hline$C P T 1 A$ & 1.05 & 1.05 & 0.12 & 0.99 \\
\hline
\end{tabular}

${ }^{1}$ Post-TMR: Cows changed at 61 DIM to a mixed feeding regime that included pasture grazing (one am grazing session of $6 \mathrm{~h}$ ) $+50 \%$ TMR (DM basis) after being fed 100\% TMR (ad libitum) during the first 60 DIM. PG: control group, cows fed a mixed feeding regime of pasture grazing (one am grazing session of 6 h) $+50 \%$ TMR (DM basis) from calving. ${ }^{2}$ Genes: $I G F 1, I G F 2$ insulin like growth factor 1 and 2; IGFBP1, $I G F B P 2, I G F B P 3, I G F B P 4, I G F B P 5, I G F B P 6=$ IGF binding proteins-1, 2, 3, 4, 5 and 6; INSR = insulin receptor; $L E P R B=$ full-lengthleptin receptor; $A C A D V L=$ Acyl-CoA dehydrogenase very long chain; $A C O X$ $=$ Acyl-CoA oxidase; $C S=$ citrate cintase; $P C=$ pyruvate carboxylase; $G 6 P C=$ glucose 6-phosphatase; $H M G C o A=$ hydroxymethylglutaryl-CoA synthase; $P D H 1 A=$ pyruvate dehydrogenase; $C P T 1 A=$ carnitinepalmitoyltransferase. 


\section{Discussion}

The inclusion of grazing, without an adaptation period, in the diet of dairy cows that were fed only TMR during early lactation, modified hepatic IGF system associated with changes in productive performance. Milk production decreased only in Post-TMR group after dietary change. Although this decrease could accompany the normal decline in the lactation curve around the peak of milk production [17], as it was only observed in Post-TMR cows, it was probably associated to a restriction in DMI and/or increased in energy requirements after the change of the diet [6]. It has been reported that not only characteristics of the pasture, but also its management can limit DMI of grazing animals [4] [18]. Bargo et al. [19] reported decreased milk production and DMI for cows grazing pasture and supplemented with TMR (as $17 \mathrm{~kg} \mathrm{DM} / \mathrm{d}$ per cow) when compared to cows fed only TMR. In addition, grazing as such produces an increase in energy expenditure (for walking and grazing) compared to animals with food easily available as a TMR [20]. This idea is supported by the fact that cows in the Post-TMR group increased estimated energy requirements maintenance [16] by $10 \%$ from -1 to +1 wk ( +55 to +69 DIM).

The observed decreases in milk yield, BW and BCS from -1 to +1 wk only in Post-TMR cows suggested that the reduction in TMR intake and the greater energy maintenance demands were not compensated by an adequate intake from pasture in these cows. Indeed, DMI and grazing behavior of the same experimental treatments were reported by [6] that despite not finding differences in average DMI and grazing behavior between Post-TMR and PG cows after the change of diet, they reported lower grazing activity on Post-TMR during the last hours in the pasture. In addition, it is also known the transition from one diet type to another causes changes in the rumen microbiota and rumen stratification [21] [22]. These changes could lead to alterations in fermentation patterns [23] and physiological and structural adaptations of the rumen epithelium [24] that could affect nutrient utilization in the gastrointestinal tract and also explain the decline in performance (milk yield, BW and BCS) in Post-TMR cows.

Dietary change in this study was done after peak milk yield and nadir of BCS [7], thus, no changes in BCS would have been expected according to the lactation stage. Nevertheless, as reported before, both, BW and BCS decreased for Post-TMR cows after the change of diet, indicating mobilization of body reserves, probably to cope with the increased maintenance requirements. Indeed, milk fatty acid profile of these cows showed an increase of preformed fatty acids, particularly of stearic acid (Barca et al. unpublished results), which may reflect lipomobilization [25]. However, NEFA concentrations did not increase in Post-TMR cows, which suggested that lipid mobilization was not extensive and/or there was a differential tissue NEFA utilization due to the increased walking and grazing activities in these cows [7]. The oxidation of mitochondrial fatty acids produces energy in muscle for muscle contraction or exercise [26].

In agreement with the inverse association between serum IGF-1 and milk production in dairy cows [27], we found that the concentrations of IGF-1 tended 
to increase after the dietary change in Post-TMR cows. The role of IGF-1 around calving, when its concentrations decreased consistent with an uncoupled somatotropic axis, mediating nutrient partitioning towards milk production has been extensively reviewed [27] [28]. Therefore, considering that in the present study the change of diet occurred after the peak of milk production, results suggested that the increase in circulating IGF-1 would modify nutrient redistribution in detriment of milk production. The increased serum IGF-1 concentrations were also consistent with an increased hepatic mRNA expression of $I G F 1$ and three of its binding proteins, IGFBP3, IGFBP5 and IGFBP6, after the change of diet only in Post-TMR cows. The association between hepatic IGF1 mRNA and circulating concentrations of IGF-1 has been previously reported [29] [30]. It is known that, once released from the cell, the majority of IGF-1 found in circulation is bound with high affinity to one or more of the 6 known IGF binding proteins. However, binary complexes that IGF-1 form with IGFBP-3 or IGFBP-5 (including the binding with the acid-labile) extend IGF-1 half-life from $10 \mathrm{~min}$ to 16 hours or longer increasing availability of IGF to cellular functions in the body [31] [32] [33]. Thus, increased serum IGF-1 could have been responded not only to a greater hepatic IGF-1 secretion, but also to an increased circulation of this hormone in blood as a ternary complex due to greater availably of IGFBP3 and IGFBP5. Consistent with our results, Fenwick et al. [30] reported increased $I G F B P 3, I G F B P 5$ and IGFBP6 mRNA expression in the liver of early lactation dairy cows with reduced milk production and moderate negative energy balance when compared with cows with greater milk production and severe negative energy balance. In addition, Coyne et al. [34] reported increased hepatic IGFBP5 mRNA in heifers fed a high n-3 polyunsaturated diet. Indeed, in the present study n-3 PUFA intake increased after the change of diet (by the inclusion of pasture) for Post-TMR cows (Barca et al. unpublished results).

The increase in $A C A D V L$ mRNA in the liver at $+1 \mathrm{wk}$ in both treatments indicated a metabolic adaptation to promote $\beta$-oxidation of fatty acids [35]. Indeed, we found a positive correlation between serum NEFA concentrations and hepatic $A C A D V L$ mRNA. The increase in liver $A C A D V L$ mRNA as lactation progresses could reflect a better liver capacity to use NEFA as fuel as has been shown previously [35]. Interestingly, although no changes in hepatic $P C$ mRNA were observed, $P D H 1 A$ mRNA increased its expression in both treatments suggesting that the shift in the metabolism later in lactation was not directed to improve gluconeogenesis but to the complete oxidation of the carbons (Krebs Cycle). Moreover, the $P D H 1 A$ to $P C$ mRNA ratio tended to increase only in Post-TMR cows after the change of diet suggesting a greater flux of pyruvate to acetyl-coA than to oxaloacetate, probably due to a reduced demand for the generation of oxaloacetate via PC [36] as milk production, thus lactose production and the need for glucose, was reduced in this group.

The results confirm that metabolic regulation in dairy cows is a dynamic system, and changes in feeding strategy without an adaptation period modified animal metabolism. In the present study, the inclusion of grazing to cows that 
were fed TMR during early lactation, increased IGF-1 concentrations and modified hepatic expression of genes related with IGF system and fatty acid metabolism indicating redistribution of nutrients and energy towards maintenance requirements (increased due to walking and grazing activity) in detriment of milk production.

\section{Acknowledgements}

The authors thank undergraduate student for assistance with animal management and sampling, and the staff of the Experimental Station Dr. Mario A. Cassinoni for animal care and assistance throughout the work. The research that gives rise to the results presented in this publication was funded by the Agencia Nacional de Investigacion e Innovación under the code ANII \#POS_2011_1_ 3577 for the graduate scholarship awarded to A. Astessiano.

\section{References}

[1] Dillon, P. (2006) Achieving High Dry-Matter Intake from Pasture with Grazing Dairy Cows. In: Elgersma, A., Ed., Fresh Herbage for Dairy Cattle, Springer, Berlin, $1-26$.

[2] Kolver, E.S. and Muller, L.D. (1998) Performance and Nutrient Intake of High Producing Holstein Cows Consuming Pasture or a Total Mixed Ration. Journal of Dairy Science, 81, 1403-1411. https://doi.org/10.3168/jds.S0022-0302(98)75704-2

[3] Chilibroste, P., Mattiauda, D.A., Bentancur, O., Soca, P. and Meikle, A. (2012) Effect of Herbage Allowance on Grazing Behavior and Productive Performance of Early Lactation Primiparous Holstein Cows. Animal Feed Science Technology, 173, 201-209. https://doi.org/10.1016/j.anifeedsci.2012.02.001

[4] Wales, W.J., Marett, L.C., Greenwood, J.S., Wright, M.M., Thornhill, J.B., Jacobs, J.L., Ho, C.K.M. and Auldist, M.J. (2013) Use of Partial Mixed Rations in PastureBased Dairying in Temperate Regions of Australia. Animal Production Science, 53, 1167-1178. https://doi.org/10.1071/AN13207

[5] Broster, W.H., Broster, V.J. and Clements, A.J. (1993) Feed Utilization by the Dairy Cow over Multiple Lactations: A Review. Livestock Production Science, 34, 1-21.

[6] Fajardo, M., Mattiauda, D.A., Motta, G., Genro, T.C., Meikle, A., Carriquiry, M. and Chilibroste, P. (2015) Use of Mixed Rations with Different Access Time to Pastureland on Productive Responses of Early Lactation Holstein Cows. Livestock Science, 181, 51-57. https://doi.org/10.1016/j.livsci.2015.09.023

[7] Astessiano, A.L., Meikle, A., Fajardo, M., Gil, J., Mattiauda, D.A., Chilibroste, P. and Carriquiry, M. (2015) Metabolic and Endocrine Profiles and Hepatic Gene Expression of Holstein Cows Fed Total Mixed Ration or Pasture with Different Grazing Strategies during Early Lactation. Acta Veterinaria Scandinavica, 57, 70. https://doi.org/10.1186/s13028-015-0163-6

[8] Schären, M., Jostmeier, S., Ruesink, S., Hüther, L., Frahm, J., Bulang, M., Meyer, U., Rehage, J., Isselstein, J., Breves, G. and Dänicke, S. (2016) The Effects of a Ration Change from a Total Mixed Ration to Pasture on Health and Production of Dairy Cows. Journal of Dairy Science, 99, 1183-1200. https://doi.org/10.3168/jds.2015-9873

[9] Schären, M., Seyfang, G.M., Steingass, H., Dieho, K., Dijkstra, J., Hüther, L., Frahm, J., Beineke, A., von Soosten, D., Meyer, U., Breves, G. and Dänicke, S. (2016) The 
Effects of a Ration Change from a Total Mixed Ration to Pasture on Rumen Fermentation, Volatile Fatty Acid Absorption Characteristics, and Morphology of Dairy Cows. Journal of Dairy Science, 99, 3549-3565.

https://doi.org/10.3168/jds.2015-10450

[10] Kelly, M.L., Berry, D.A., Dwyer, J.M., Griinari, J.M., Chouinard, P.Y., Amburgh, M.E.W. and Bauman, D.E. (1998) Dietary Fatty Acid Sources Affect Conjugated Linoleic Acid Concentrations in Milk from Lactating Dairy Cows. Journal of Nutrition, 128, 881-885.

[11] Agenäs, S, Holtenius, K., Griinari, M. and Burstedt, E. (2002) Effects of Turnout to Pasture and Dietary Fat Supplementation on Milk Fat Composition and Conjugated Linoleic Acid in Dairy Cows. Acta Agriculturae Scandinavica, Section A. Animal Science, 52, 25-33.

[12] Edmonson, A.J., Lean, I.J., Weaver, L.D., Farver, T. and Webster, G.A. (1989) Body Condition Scoring Chart for Holstein Dairy Cows. Journal of Dairy Science, 72, 68-78. https://doi.org/10.3168/jds.S0022-0302(89)79081-0

[13] Carriquiry, M., Webe, W.J., Fahrenkrug, S.C. and Crooker, B.A. (2009) Hepatic Gene Expression in Multiparous Holstein Cows Treated with Bovine Somatotropin and Fed n-3 Fatty Acids in Early Lactation. Journal of Dairy Science, 92, 4889-900. https://doi.org/10.3168/jds.2008-1676

[14] Astessiano, A.L., Perez Clariget, R., Quintans, G., Soca, P. and Carriqury, M. (2012) Effects of a Short-Term Increase in the Nutritional Plane before the Mating Period on Metabolic and Endocrine Parameters, Hepatic Gene Expression and Reproduction in Primiparous Beef Cows on Grazing Conditions. Journal of Animal Physiology and Animal Nutrition, 96, 535-544. https://doi.org/10.1111/j.1439-0396.2011.01178.x

[15] Pfaffl, M.W., Georgieva, T.M., Georgiev, I.P., Ontsouka, E., Hageleit, M. and Blum, J.W. (2002) Real-Time RT-PCR Quantification of Insulin-Like Growth Factor (IGF)-1, IGF-1 Receptor, IGF-2, IGF-2 Receptor, Insulin Receptor, Growth Hormone Receptor, IGF-Binding Proteins 1, 2 and 3 in the Bovine Species. Domestic Animal Endocrinology, 22, 91-102. https://doi.org/10.1016/S0739-7240(01)00128-X

[16] NRC (2001) Nutrient Requirements of Dairy Cattle. 7th Revised Edition, National Academies Press, Washington DC.

[17] Gustafsson, A.H. and Palmquist, D.L. (1993) Diurnal Variation of Rumen Ammonia, Serum Urea, and Milk Urea in Dairy Cows at High and Low Yields. Journal of Dairy Science, 76, 475-484. https://doi.org/10.3168/jds.S0022-0302(93)77368-3

[18] Chilibroste, P., Soca, P., Mattiauda, D.A., Bentancur, O. and Robinson, P.H. (2007) Short Term Fasting as a Tool to Design Effective Grazing Strategies for Lactating Dairy Cattle: A Review. Australian Journal of Experimental Agriculture, 47, 10751084. https://doi.org/10.1071/EA06130

[19] Bargo, F., Muller, L.D., Delahoy, J.E. and Cassidy, T.W. (2002) Performance of High Producing Dairy Cows with Three Different Feeding Systems Combining Pasture and Total Mixed Rations. Journal of Dairy Science, 85, 948-2963.

[20] Roca-Fernandez, A.I., Ferris, C.P. and Gonzales-Rodriguez, A. (2013) Short Communication: Behavioural Activities of Two Dairy Cow Genotypes (Holstein-Friesian vs. Jersey $\times$ Holstein-Friesian) in Two Milk Production Systems (Grazing vs. Confinement). Spanish Journal of Agricultural Research, 11, 120-126. https://doi.org/10.5424/sjar/2013111-2682

[21] Russell, J.B. and Rychlik, J.L. (2001) Factors That Alter Rumen Microbial Ecology. Science, 292, 1119-1122. https://doi.org/10.1126/science.1058830

[22] Storm, A.C. and Kristensen, N.B. (2010) Effects of Particle Size and Dry Matter 
Content of a Total Mixed Ration on Intraruminal Equilibration and Net Portal Flux of Volatile Fatty Acids in Lactating Dairy Cows. Journal of Dairy Science, 93, 42234238. https://doi.org/10.3168/jds.2009-3002

[23] Van Houtert, M. (1993) The Production and Metabolism of Volatile Fatty Acids by Ruminants Fed Roughages: A Review. Animal Feed Science and Technology, 43, 189-225. https://doi.org/10.1016/0377-8401(93)90078-X

[24] Gäbel, G., Aschenbach, J.R. and Muller, F. (2002) Transfer of Energy Substrates across the Ruminal Epithelium: Implications and Limitations. Animal Health Research Reviews, 3, 15-30. https://doi.org/10.1079/AHRR200237

[25] Rukkwamsuk, T., Geelen, M.J.H., Kruip, T.A.M. and Wensing, T. (2000) Interrelation of Fatty Acid Composition in Adipose Tissue, Serum, and Liver of Dairy Cows during the Development of Fatty Liver Postpartum. Journal of Dairy Science, 83, 52-59. https://doi.org/10.3168/jds.S0022-0302(00)74854-5

[26] Drackley, J.K., Beaulieu, A.D. and Elliott, J.P. (2001) Responses of Milk Fat Composition to Dietary Fat or Nonstructural Carbohydrates in Holstein and Jersey Cows. Journal of Dairy Science, 84, 1231-1237. https://doi.org/10.3168/jds.S0022-0302(01)74584-5

[27] Lucy, M.C. (2008) Functional Differences in the Growth Hormone and Insulin-Like Growth Factor Axis in Cattle and Pigs: Implications for Post-Partum Nutrition and Reproduction. Reproduction in Domestic Animals, 43, 31-39. https://doi.org/10.1111/j.1439-0531.2008.01140.x

[28] Bauman, D.E. (2000) Regulation of Nutrient Partitioning during Lactation: Homeostasis and Homeorhesis Revisited. In: Cronje, P.J., Ed., Ruman Physiology. Digestion. Metabolism and Growth and Growth and Reproduction, CAB Publishing, New York, 311-327.

[29] Radcliff, R.P., McCormack, B.L., Crooker, B.A. and Lucy, M.C. (2003) Growth Hormone $(\mathrm{GH})$ Binding and Expression of GH Receptor 1A mRNA in Hepatic Tissue of Periparturient Dairy Cows. Journal of Dairy Science, 86, 3933-3940. https://doi.org/10.3168/jds.S0022-0302(03)74002-8

[30] Fenwick, M.A., Fitzpatrick, R., Kenny, D.A., Diskin, M.G., Patton, J., Murphyd, J.J. and Wathes, D.C. (2008) Interrelationships between Negative Energy Balance (NEB) and IGF Regulation in Liver of Lactating Dairy Cows. Domestic Animal Endocrinology, 34, 31-44. https://doi.org/10.1016/j.domaniend.2006.10.002

[31] Rajaram, S., Baylink, D.J. and Mohan, S. (1997) Insulin-Like Growth Factor-Binding Proteins in Serum and Other Biological Fluids: Regulation and Functions. Endocrine Reviews, 18, 801-831. https://doi.org/10.1210/er.18.6.801

[32] Twigg, S.M. and Baxter, R.C. (1998) Insulin-Like Growth Factor (IGF)-Binding Protein 5 Forms an Alternative Ternary Complex with IGFs and the Acid-Labile Subunit. The Journal of Biological Chemistry, 273, 6074-6079.

[33] Baxter, R.C. (2014) IGF Binding Proteins in Cancer: Mechanistic and Clinical Insights. Nature Reviews Cancer, 14, 329-341. https://doi.org/10.1038/nrc3720

[34] Coyne, G.S., Kenny, D.A. and Waters, S.M. (2011) Effect of Dietary n-3 Polyunsaturated Fatty Acid Supplementation on Bovine Uterine Endometrial and Hepatic Gene Expression of the Insulin-Like Growth Factor System. Theriogenology, 75, 500-512. https://doi.org/10.1016/j.theriogenology.2010.09.018

[35] Loor, J.J., Dann, H.M., Everts, R.E., Oliveira, R., Green, C.A., Guretzky, N.A., et al. (2005) Temporal Gene Expression Profiling of Liver from Periparturient Dairy Cows Reveals Complex Adaptive Mechanisms in Hepatic Function. Physiological Genomics, 23, 217-226. https://doi.org/10.1152/physiolgenomics.00132.2005 
[36] Aschenbach, J.R., Kristensen, N.B., Donkin, S.S., Hammon, H.M. and Penner, G.B. (2010) Gluconeogenesis in Dairy Cows: The Secret of Making Sweet Milk from Sour Dough. IUBMB Life, 62, 869-877. https://doi.org/10.1002/iub.400 


\section{Supplementary}

Table S1. Primers used for the quantification of target and endogenous control gene cDNA.

\begin{tabular}{|c|c|c|c|c|c|}
\hline Gene $^{1}$ & Accession no. ${ }^{2}$ & & Primer sequence & Length (bp) & Efficiency \\
\hline \multirow[b]{2}{*}{$I G F 1$} & \multirow[b]{2}{*}{ XM_612412 } & Sense & CCAGACAGGAATCGTGGATG & \multirow[b]{2}{*}{89} & \multirow[b]{2}{*}{1.27} \\
\hline & & Antisense & ACTTGGCGGGCTTGAGAG & & \\
\hline \multirow{2}{*}{$I G F 2$} & \multirow{2}{*}{ NM_174087 } & Sense & TTGCAGGTAGGCTTGTCCTT & \multirow{2}{*}{98} & \multirow{2}{*}{1.09} \\
\hline & & Antisense & CAGGTTTGGGTCTTTGGTGT & & \\
\hline \multirow{2}{*}{$I G F B P 1$} & \multirow{2}{*}{ NM_174554 } & Sense & TACAGAAGTGGAAGGAGCCCT & \multirow{2}{*}{127} & \multirow{2}{*}{1.21} \\
\hline & & Antisense & AATCCATTCTTGTTGCAGTTT & & \\
\hline \multirow{2}{*}{$I G F B P 2$} & \multirow{2}{*}{ NM_174555 } & Sense & ATGCGCCTTCCGGATGA & \multirow{2}{*}{83} & \multirow{2}{*}{1.15} \\
\hline & & Antisense & GTTGTACAGGCCATGCTTGTCA & & \\
\hline \multirow{2}{*}{$I G F B P 3$} & \multirow{2}{*}{ NM_174556 } & Sense & AGCACAGACACCCAGAACTTCT & \multirow{2}{*}{86} & \multirow{2}{*}{1.19} \\
\hline & & Antisense & TTCAGCGTGTCTTCCATTTCC & & \\
\hline \multirow{2}{*}{$I G F B P 4$} & \multirow{2}{*}{ NM_174557 } & Sense & ARGTGCCTGATGGAGAAAGG & \multirow{2}{*}{145} & \multirow{2}{*}{0.98} \\
\hline & & Antisense & AAGGCAGAGCCACAGACAGT & & \\
\hline \multirow{2}{*}{$I G F B P 5$} & \multirow{2}{*}{ NM_1105327 } & Sense & CAAGCCAAGATCGAAAGAGACT & \multirow{2}{*}{86} & 101 \\
\hline & & Antisense & AAGATCTTGGGCGAGTAGGTCT & & 1.01 \\
\hline IGFBPG & NM 1040495 & Sense & GGAGAGAATCCCAAGGAGAGTAA & 100 & 0.97 \\
\hline & & Antisense & GAGTGGTAGAGGTCCCCGAGT & & \\
\hline$I N S R$ & XM 5905524 & Sense & CTGAAGCCAAGGCAGATGATATT & 77 & 000 \\
\hline INSK & XMI_590532.4 & Antisense & GCCACATCAAGTGAACAACGTT & 17 & 0.90 \\
\hline$L E P R B$ & AB199589 & Sense & ACCACACCTTCCGTTCTCAG & 164 & \\
\hline$\angle E P K B$ & АВ199589 & Antisense & GGGACAACACTCTTGACTC & 164 & 1.08 \\
\hline$A C A D V I$ & NM 1744942 & Sense & CCAGC-CCCTG-TGGAA-AATAC-TA & 60 & 10 \\
\hline$A C A D V L$ & NM_174494.2 & Antisense & GCCCC-CGTTA-CTGAT-CCAA & 62 & 1.04 \\
\hline$C s$ & NM 0010447211 & Sense & AGCCAAGATACCTGTTCCTC & 217 & 10 \\
\hline & & Antisense & TGTGCTGGAAGAAACGATTGC & & \\
\hline$P C$ & NM 001040716 & Sense & AGGGAAGCTCCTATTTGCTCC & 234 & 1.15 \\
\hline & & Antisense & CGGTGGATGTGGTCCTTCTCT & & \\
\hline$C 6 P C$ & NM 00151 & Sense & TGAGGATGGAGAAGGGAATG & 203 & 102 \\
\hline $00 \%$ & NVIVI_OUIJI & Antisense & TGAACCAATCCTGGGAGTTC & & 1.02 \\
\hline$P D H] A$ & NM 000284 & Sense & ATCCTCTGTCGTCCCCTTCT & 89 & 0.98 \\
\hline PDHIA & NM_000284 & Antisense & CACCTCATGCGAAGAGTTGA & & \\
\hline$C P T 1 A$ & NM 001876 & Sense & CAAAACCATGTTGTACAGCTTCCA & 140 & 101 \\
\hline & & Antisense & GCTTCCTTCATCAGAGGCTTCA & & \\
\hline$A C T B$ & BT030480 & Sense & CGTGGCTACAGCTTCACC & 53 & 115 \\
\hline & & Antisense & GAAATCGTCCGTGACATCAA & 53 & \\
\hline$H P R T$ & XM 580802 & Sense & TGGAGAAGGTGTTTATTCCTCATG & 105 & 1.05 \\
\hline & & Antisense & CACAGAGGGCCACAATGTGA & 105 & \\
\hline RPS9 & NM 1101152 & Sense & CCTCGACCAAGAGCTGAAG & 63 & 1.03 \\
\hline & & Antisense & CCTCCAGACCTCACGTTTGTTC & & \\
\hline
\end{tabular}

${ }^{1} G H R=$ growth hormone receptor, $G H R 1 A=$ growth hormone receptor $1 \mathrm{~A}, I G F 1=$ insulin-like growth factor-I, $I G F 2=$ insulin-like growth factor-II, $I G F 1 R=$ insulin-like growth factor-I receptor, IGF binding proteins-1 to $6(I G F B P 1, I G F B P 2, I G F B P 3, I G F B P 4, I G F B P 5, I G F B P 6), I N S R=$ insulin receptor, $L E P R B=$ full-length leptin receptor; $A C A D V L=$ Acyl-CoA dehydrogenase very long chain; $C S=$ citrate cintase; $P C=$ pyruvate carboxylase; $G 6 P C=$ glucose 6-phosphatase; $P D H 1 A=$ pyruvate dehydrogenase; $C P T 1 A=$ carnitine palmitoyl transferase, and $A C T B=B$-actin, $H P R T=$ hypoxanthine phosphoribosyltransferase and $R P S 9=$ ribosomal protein $S 9$ as an endogenous control gene. ${ }^{2} \mathrm{Gene}$ Bank bovine sequences. 
Submit or recommend next manuscript to SCIRP and we will provide best service for you:

Accepting pre-submission inquiries through Email, Facebook, LinkedIn, Twitter, etc. A wide selection of journals (inclusive of 9 subjects, more than 200 journals)

Providing 24-hour high-quality service

User-friendly online submission system

Fair and swift peer-review system

Efficient typesetting and proofreading procedure

Display of the result of downloads and visits, as well as the number of cited articles Maximum dissemination of your research work

Submit your manuscript at: http://papersubmission.scirp.org/

Or contact ojas@scirp.org 